\title{
Life Satisfaction among Outbound Students in Northern Sweden
}

\author{
Per A Nilsson ${ }^{1, *}$ \\ ${ }^{1}$ Department of Geography and Economic History, Umeå University, Sweden \\ *Correspondence: International Office, Umeå University, Sweden. Tel: 46-90-786-5000
}

Received: July 12, 2015

Accepted: August 8, 2015 Online Published: August 15, 2015

doi:10.5430/wje.v5n4p87

URL: http://dx.doi.org/10.5430/wje.v5n4p87

\begin{abstract}
The transition from one's home country to a university abroad can be demanding. This study is a follow-up study exploring life satisfaction among outbound students. Outbound students at Umeå University, Sweden, were surveyed before and after experiencing studying abroad. Thus, the students' life satisfaction could be compared after an international experience with the situation before studying abroad. The same students (individuals) were surveyed both times. The study is based on an initial sample of 143 outbound students, where 57 answered both surveys. It was found that students reported lower levels of satisfaction regarding their study situation, life as a whole, contacts with friends and leisure time after a period abroad. Furthermore, after returning the students reported lower levels of somatic health and psychological health compared with before studying abroad. These were items that significantly affected students' life satisfaction. However, most of the respondents were happy with their daily life activities and partner relationships.
\end{abstract}

Keywords: Outbound Students, Student Mobility, Life Satisfaction, Sweden

\section{Introduction}

This article explores student mobility and the experiences students gained after a period of studying abroad. Many students have international experiences during their studies (Streitwieser, Le \& Rust, 2012). Since the 1970s, student mobility has grown remarkably fast. Today, approximately more than 4.5 million students study abroad (OECD, 2014). As the number of international students increase globally, the need to understand and to address their cultural and psychological adjustment to a new country becomes more important. Thus, the increase in the number of students studying abroad leads to questions about the students' experiences and whether their expectations were met. One aspect of this is reported life satisfaction among outbound students.

Studies of student mobility have become a comprehensive area of research (cf. Streitwieser, 2012) but few studies cover one important aspect of student mobility, the topic of life satisfaction. During their university years, students may experience considerable life stress because of numerous challenging life events. Moreover, studying in a foreign country is demanding, students are away from home and this, together with financial concerns, have been identified as common stressors among university students (Bhandari, 2012). There are some studies that indicate the extent of loneliness and/or isolation among international students (cf. Sandhu, 1994; Sawir, Marginson, Deumert, Nyland \& Ramia, 2008; Russell, Rosenthal \& Thomson, 2010). International students face both shared and unique problems. They face problems of living in a foreign culture, such as racial discrimination, language problems, accommodation difficulties, dietary restrictions, financial stress and misunderstandings. Exposure to an unfamiliar environment can create anxiety, confusion and depression leading to experiences of, among other things, loneliness, insomnia and physical illness, all of which can interfere with students' studies, friendships and social life (Lin, Jun-Chich \& Yl, 1997).

In this study, we surveyed life satisfaction among outbound students, that is, students going abroad for tertiary studies as part of a program (credit mobility). Life satisfaction is a generic concept representing an individual's contentment with his or her life, i.e. the degree of an individual's subjective appraisal as to whether his or her aspirations and achievements have been accomplished (Jacobsson \& Lexell, 2013). Thus, learning more about whether and how aspects of life satisfaction have been affected after experiencing a study abroad is important for a better understanding of student mobility.

This study focuses on the situation of outbound students and their reported life satisfaction. The hypothesis tested is 
whether studying abroad has an impact on health and life satisfaction. The aim of this study is to investigate life satisfaction among a group of outbound students and to follow up on their reported life satisfaction after studying abroad for approximately six months.

\section{Methods}

\subsection{Participants}

The surveys were directed at outbound students at Umeå University, a comprehensive university in northern Sweden with approximately 33,000 students, during the 2007/2008 academic year. All outbound students received the first survey in August 2007 prior to their departure and a follow-up survey in March 2008. The study was a web-based survey of all outbound students studying at partner universities with whom Umeå University has a University-wide agreement with. Thus, the analyses are based on survey data monitoring the students' levels of life satisfaction when they were about to leave Sweden and after approximately six months studying abroad. Furthermore, the analyses are therefore based on data from a survey monitoring their life satisfaction prior to leaving Sweden and a follow-up survey when they returned. Reported life satisfaction was measured before and after experiencing studying abroad. The same students (individuals) were surveyed. The students arrive with a set of feelings and emotions and depart with their own unique experience of reported life satisfaction.

Non-respondents in the follow-up survey were mainly the result of students having changed their e-mail addresses and, therefore, not being possible to reach. An analysis of the non-participants does not indicate any bias with respect to gender, age or study programmes. The non-respondents in the follow-up survey were compared with the respondents in both surveys regarding life satisfaction on the LiSat-11 prior leaving Sweden. The non-respondents reported significantly lower satisfaction on two items, contact with friends $(\mathrm{p}=0.026)$ and activities of daily living $(\mathrm{p}=0.025)$.

Table 1. A Comparison between the First and the Follow-Up Surveys

\begin{tabular}{lll}
\hline & $\begin{array}{l}\text { Respondents } \\
\text { first survey } \mathrm{n}=80\end{array}$ & $\begin{array}{l}\text { Respondents in both } \\
\text { surveys } \mathrm{n}=57\end{array}$ \\
\hline Gender & & \\
Female & $47(59 \%)$ & $37(64.9 \%)$ \\
Male & $33(41 \%)$ & $20(35.1 \%)$ \\
\hline Mean age & $24.06 \pm 2.9$ & $24.09 \pm 3.3$ \\
\hline Upbringing & & \\
Sweden & $71(89 \%)$ & $51(90 \%)$ \\
Abroad & $9(11 \%)$ & $6(10 \%)$ \\
\hline Lived a period in a foreign country before studying abroad & & \\
Yes & $40(50 \%)$ & $28(49 \%)$ \\
No & $40(50 \%)$ & $29(51 \%)$ \\
\hline Field of studies & & \\
Humanities & $2(2.5 \%)$ & $2(3.5 \%)$ \\
Social Sciences (incl. Law \& Business) & $60(75 \%)$ & $41(71.9 \%)$ \\
Teacher Training & $3(3.8 \%)$ & $2(3.5 \%)$ \\
Natural Sciences and Technology & $9(11.3 \%)$ & $7(12.3 \%)$ \\
Medicine, Odontology and Healthcare & $4(5.0 \%)$ & $3(5.3 \%)$ \\
Art and Fine Art & $2(2.5 \%)$ & $2(3.5 \%)$ \\
\hline Length of studies abroad & & \\
One semester & $71(89 \%)$ & $54(95 \%)$ \\
Two semesters & $9(11 \%)$ & $3(5 \%)$ \\
\hline
\end{tabular}

Of the initial sample of 143 outbound students enrolled in an exchange program in the autumn term 2007, 62 had answered both surveys six months later, and 57 of the respondents could be matched and linked between the respondents in both surveys. Thus, we have surveyed the same individuals over time.

\subsection{The Questionnaire}

The survey used the Life Satisfaction Questionnaire (LiSat-11).The questionnaire comprises estimations of life 
satisfaction in general as well as satisfaction with specific aspects of one's life: satisfaction with one's academic situation, finances, leisure time, contact with friends and acquaintances, daily life, family life, partnership, somatic health, and psychological health (Fugl-Meyer, A-R., Melin \& Fugl-Meyer, K.S., 2002). A Likert scale was used and levels of satisfaction are estimated on a six-grade scale (from $1=$ very dissatisfied to $6=$ very satisfied); higher scores indicate higher levels of life satisfaction. For comparison purposes, the scale was dichotomized into either satisfied (5-6) or not satisfied (1-4).

LiSat-11 is a further development of LiSat-9 (Fugl-Meyer, Bränholm \& Fugl-Meyer, 1991), has a stable construct, and has been found to be valid for the general population. Levels of satisfaction are rated on a six-grade ordinal scale (from $1=$ very dissatisfied to $6=$ very satisfied); higher scores indicate higher levels of life satisfaction. In accordance with previous studies and for comparison purposes using the LiSat-11 (Fugl-Meyer et al., 2002; Melin, Fugl-Meyer \& Fugl-Meyer, 20013), the scale was dichotomized into either satisfied 5-6 or dissatisfied 1-4.

\subsection{Statistics}

All statistical analysis was performed using SPSS, version 21.0 for Windows. A statistical data evaluation was performed using non-parametric tests as some of the samples were not normally distributed and the LiSat-11 is an ordinal scale with 6 categories. The Wilcoxon signed ranked test was used for the study of paired observations, e.g. to compare answers on the surveys after the respondents had studied for more than six months with their answers when they had just left Sweden to study abroad. The Mann-Whitney test was used to compare differences between groups. The level of statistical significance was set to $\mathrm{p}<0.05$.

\subsection{Limitations}

The Umeå University case was chosen because of existing good collaboration between the author and the university's international office. However, the study relies on a relatively small group of outbound students. Moreover, the students were followed up after a comparatively short period of time. Additionally, the case is from a university in Northern Europe, Scandinavia. These limitations naturally make any conclusions drawn from the study tentative.

\section{Results from the Study}

Data on the 57 participants are presented in Table 2. Levels of satisfaction with both somatic health and psychological health were reported as much lower after a period abroad. Before leaving Sweden, $75.5 \%$ of the respondents reported that they were satisfied to very satisfied with their psychological health. After studying abroad, the proportion had dropped to approximately $58 \% .65 \%$ of the respondents were satisfied very satisfied with life as a whole after a period studying abroad. This can be compared with $82.5 \%$ before leaving for studies abroad. Approximately $61 \%$ reported after the experience that they were satisfied to very satisfied with their leisure time, i.e. a ten percent decrease since leaving Sweden. Study situation dropped from approximately $60 \%$ to $54 \%$. Satisfaction with contact with friends was also reported as having decreased by approximately ten percent.

Compared with their situation before studying abroad, the students reported that activities of daily living had increased from approximately $89 \%$ to $91 \%$. Satisfaction with partner relationship was also reported as increased, from approximately $46 \%$ to $49 \%$. There were no changes in levels of satisfaction with finances or family life. Approximately $19 \%$ of the respondents reported being satisfied to very satisfied with their finances before and after the experience. Approximately $60 \%$ of the respondents reported that they were satisfied to very satisfied with family life.

Gender differences were also examined. The study showed some differences in reported life satisfaction when male and female students were compared before and after experiencing study abroad. Before leaving, the female students reported significantly higher levels of satisfaction with contacts with friends $(p=0.043)$. After studying abroad, the female students reported a significantly decrease in satisfaction for somatic health $(\mathrm{p}=0.047)$.

Furthermore, the study also compared within-group changes for female students and male students before and after studying abroad. For females, life satisfaction regarding life as a whole $(p=0.029)$, contact with friends $(p=0.034)$, somatic health $(\mathrm{p}=0.025)$ and psychological health $(\mathrm{p}=0.046)$ was reported significantly lower after studying abroad. For men, life satisfaction for life as a whole $(\mathrm{p}=0.029)$ and psychological health $(\mathrm{P}=0.047)$ was reported to have significantly decreased after studying abroad. 
Table 2. Self-reported Levels (\%) of Satisfaction with Life. Outgoing Exchange Students from Umeå University

\begin{tabular}{|c|c|c|c|c|c|}
\hline SATISFIED WITH & $\begin{array}{c}\text { BEFORE } \\
\text { LEAVING } \\
\text { SATISFIED } \\
(\%) \\
\end{array}$ & $\begin{array}{c}\text { BEFORE } \\
\text { LEAVING } \\
\text { MEAN (SD) } \\
(\mathrm{N}=57) \\
\end{array}$ & $\begin{array}{c}\text { AFTER } \\
\text { RETURNING } \\
\text { SATISFIED } \\
(\%) \\
\end{array}$ & $\begin{array}{c}\text { AFTER } \\
\text { RETURNING } \\
\text { MEAN (SD) } \\
(\mathrm{N}=57) \\
\end{array}$ & $\begin{array}{c}\text { P-VAL } \\
\text { UE }\end{array}$ \\
\hline Life as a whole & 82.5 & $5.11(0.880)$ & 65.0 & $4.72(1.013)$ & 0.002 \\
\hline Study situation & 59.7 & $4.70(0.906)$ & 54.4 & $4.46(1.059)$ & 0.122 \\
\hline Economy & 19.3 & $3.65(1.110)$ & 19.3 & $3.46(1.226)$ & 0.278 \\
\hline Leisure & 72.0 & $4.86(0.833)$ & 61.4 & $4.63(1.263)$ & 0.253 \\
\hline Contact with friends & 77.2 & $5.14(0.811)$ & 68.4 & $4.77(1.086)$ & 0.017 \\
\hline Activities of daily living & 89.5 & $5.35(1.077)$ & 91.2 & $5.37(0.993)$ & 0.964 \\
\hline Family life & 59.7 & $\begin{array}{c}5.40(0.955) \\
(\mathrm{n}=44)\end{array}$ & 59.7 & $\begin{array}{c}5.11(0.920) \\
(\mathrm{n}=44)\end{array}$ & 0.079 \\
\hline Partner relationship & 45.6 & $\begin{array}{c}5.32(0.912) \\
(\mathrm{n}=36)\end{array}$ & 49,1 & $\begin{array}{c}5.08(1.204) \\
(\mathrm{n}=36)\end{array}$ & 0.624 \\
\hline Somatic health & 77.2 & $5.18(0.826)$ & 66.7 & $4.75(1.169)$ & 0.027 \\
\hline Psychological health & 75.5 & $5.00(0.982)$ & 57.9 & $4.46(1.402)$ & 0.005 \\
\hline
\end{tabular}

\section{Discussion}

The findings of the study showed lower levels of somatic health and psychological health after a period abroad. Previous studies indicates that international students experience problems and they also experience types of problems that are different to those of domestic students. International students' reports a number of problems related to adapting to a new culture. They are living in unfamiliar surroundings and unaware of available services. Some students are at risk of health problems. Therefore, life satisfaction is an indicator of students' wellbeing. Life satisfaction has an indirect effect on student mobility and is often an invisible problem. The direct effects on student mobility are obvious; these include receiving a degree from a foreign university or making a start on an international career. Studies in life satisfaction indicate the importance of social support. They also indicate that emotional loneliness is a negative predictor for life satisfaction (Salimi, 2011; Yalçun, 2011). This study also showed that life as a whole is affected after a period abroad. However, financial worries could not be confirmed among this group of Swedish outbound students. Many studies show that money worries have a significant impact on life satisfaction (Paolini, Yanez \& Kelly., 2006). In a study by Lackland Sam (2001), it was found that factors such as the number of friends, satisfaction with finances, perceived discrimination and information received prior to a foreign stay significantly affected students' life satisfaction. This study also found that satisfaction regarding contact with friends, leisure and health was affected by a period of studying abroad.

This study also examined gender differences. Female students reported that life satisfaction had decreased on a total of four items in comparison with two items reported by the male students. Other studies have indicated that female students are more satisfied than men, and that, male students report significantly greater emotional loneliness than female students (Salimi, 2011; Yalçun, 2011). However, this study cannot confirm the findings of those studies.

Previous research indicates that individuals who are less satisfied with life report higher levels of anxiety. In this study, satisfaction with both somatic health and psychological health was reported as being reduced after a period of studying abroad. We know from other studies that students who sleep less tend to be less psychological healthy (Kelley, 2004). Individuals who score high on worry, score lower on life satisfaction than individuals who score low on worry (Paolini et al., 2006). Other studies have confirmed that stress levels are considerably higher among overseas students when compared with local students. They feel more pressure from their families to succeed, less competent in academic skills and are misunderstood by academic staff (Burns, 1991).

Being a contemporary international student is different from what it was in the past. Among other things, social media can help students to stay connected with their family and friends, creating a sense of home away from home (Gomes, Berry, Alzougool \& Chang, 2014). Even if technical facilities and devices continue to improve the situation for all international students, problems with adapting need to be addressed. When in unfamiliar surroundings, foreign students fail to actively seek help (cf. Russel et al., 2010; Morris-Lange \& Brands 2015). Therefore, universities need to be aware of students at risk.

Many studies on life satisfaction have been carried out among domestic students, i.e. students studying within their own country (cf. Bugay, 2007; Dwyer, 2008; Yalçun, 2011). Fewer studies have investigated the specific situation of 
international students in general. Nonetheless, in recent years some very interesting and promising studies have investigated life satisfaction among international students. Sawir et al. (2008) found that international students can be grouped into three categories 'personal loneliness', 'social loneliness' and 'cultural loneliness'. Furthermore, Russell et al. (2010) categorised international students depending on how they were connected, and they identified students who were 'positively connected', 'unconnected and stressed', 'distressed and risk-taking'. Finally, Sandhu (1994) argued that two major types of factors are responsible for international students' psychological problems. Intrapersonal factors, i.e. roots within the self, and interpersonal factors, i.e. related to students' environment, cultural milieu and surroundings. It is important to note that both types interact and are generally intertwined. According to Sandhu (1994), most of the problems international students face are related to intrapersonal factors. In addition, Kondakci (2011) found that establishment of regional hubs with students who originate from neighbouring countries can reduce problems with adjusting to a new county. Thus, the students are comfortable with the cultural, social and academic experiences. Therefore, regional hubs are becoming more attractive due to lower travel costs and cultural familiarity. One can observe an increase of student mobility in regions as Arab States, Central and Eastern Europe and Sahara Africa (UNESCO, 2014).

\section{Conclusion}

This study explores life satisfaction among a group of outbound students before and after experiencing studying abroad. The respondents reported significantly lower satisfaction on four items in the LiSat-11 survey. Life as a whole $(\mathrm{p}=0.002)$, contact with friends $(\mathrm{p}=0.017)$, somatic health $(\mathrm{p}=0,027)$ and psychological health $(\mathrm{p}=0.005)$. There was compelling support for the hypothesis that studying abroad has an impact on health and life satisfaction. Thus, how students are connected is crucial for their wellbeing and for avoiding feelings of loneliness and isolation.

Most intriguing and deserving of future study is the subject of addressing the imbalance in life satisfaction between domestic and international students. Possible solutions may include creating stronger social networks, more accessible accommodation, systems to ensure safety and security, and mechanisms for developing peer mentoring.

\section{References}

Bhandari, P. (2012). Stress and health related quality of life of Nepalese students studying in South Korea: A cross sectional study. Health and Quality of Life Outcomes, 10(26). http://www.hqlo.com/content/10/1/26

Bugay, A. (2007). Loneliness and life satisfaction of Turkish university students. Education in a Changing Environment Conference Proceedings, Education Development Unit, University of Salford, Salford. Retrieved from www.ece.salford.ac.uk/proceedings/papers/38_07.pdf

Burnes, R. B. (1991). Study and Stress among First Year Overseas Students in an Australian University. Higher Education Research \& Development, 10(1), 61-77

Dwyer, M. (2008). Need for Cognition, Life Satisfaction, and Academic Achievement. Epistimi, 3, 12-13.

Fugl-Meyer A-R, Bränholm I-B \& Fugl-Meyer K.S. (1991). Happiness and domain specific life satisfaction in adult northern Swedes. Clinical Rehabilitation, 5, 25-33

Fugl-Meyer, A.R., Melin, R., \& Fugl-Meyer, K.S. (2002). Life satisfaction in 18- to 64-year-old Swedes: in relation to gender, age, partner and immigrant status. Journal of Rehabilitation Medicine, 34(5), 239-246.

Gomes, C., Berry, M., Alzougool, B., \& Chang, S. (2014). Home Away from Home: International Students and their Identity-Based Social Networks in Australia. Journal of International Students, 4(1), 2-15

Jacobsson, L., \& Lexell, J. (2013). Life satisfaction 6-15 years after a traumatic brain injury. Journal of Rehabilitation Medicine, 45(10), 1010-5. http://dx.doi.org/10.2340/16501977-1204

Kelly, W. E. (2004). Sleep-length and life satisfaction in a college student sample. College Student Journal, 38(3), $428-430$

Kondakci, Y. (2011). Student mobility reviewed: attraction and satisfaction of international students in Turkey. Higher Education, 62(5), 573-592. http://dx.doi.org/10.1007/s10734-011-9406-2

Lackland Sam, D. (2001). Satisfaction with life among international students: an exploratory study. Social Indicators Research, 53, 315-337.

Lin, Jun-Chich, G., \& YI, J.K. (1997) Asian International Students Adjustment: Issues and Program Suggestions. College Student Journal, 4, 473-480 
Melin R., Fugl-Meyer K.S., \& Fugl-Meyer A.R. (2003). Life satisfaction in 18- to 64-year-old Swedes: in relation to education, employment situation, health and physical activity. Journal of Rehabilitation Medicine, 35, 84-90.

Morris-Lange, S., \& Brands, F. (2015). Train and retain: Career support for international students in Canada, Germany, the Netherlands and Sweden, SVR's Research Unit: Study 2015-2. Berlin, Germany. Retrieved from https://www.hollandalumni.nl/news/SVRResearchUnit_2015_TrainandRetain_final.pdf

OECD (2014). Education at a Glance 2014: OECD Indicators. OECD Publishing, Paris. Retrieved from http://www.oecd-ilibrary.org/docserver/download/9614011e.pdf?expires $=1414758769 \& \mathrm{id}=\mathrm{id} \&$ accname $=$ ocid4 1009790\&checksum $=$ CB4B6D2AD3C7F2B407AB853EC5B71BC9

Paolini, L., Yanez, A. P., \& Kelly, W. (2006). An Examination of Worry and Life Satisfaction among College Students. Individual Differences Research, 4(4), 331-339.

Russell, J., Rosenthal, D., \& Thomson, G. (2010). The international student experience: Three styles of adaption. Higher education, 60(2), 235-249. http://dx.doi.org/10.1007/s10734-009-9297-7

Salimi, A. (2011). Social-Emotional Loneliness and Life Satisfaction. Procedia - Social and Behavioral Sciences, 29, 292-295. http://dx.doi.org/10.1016/j.sbspro.2011.11.241

Sandhu, D.S. (1994). An examination of the psychological needs of the international students: Implications for counselling and psythotherapy. International Journal for the Advancement of Counselling, 17, 229-239.

Sawir, E., Marginson, S., Deumert, A., Nyland, C., \& Ramia, G. (2008). Loneliness and International Students: An Australian Study. Journal of Studies in International Education, 2, 148-180.

Streitwieser, B. T., Le, E., \& Rust., E. (2012). Research on study abroad, mobility, and student exchange in comparative education scholarship. Research in Comparative \& International Education, 1, 5-19. http://dx.doi.org/10.2304/rcie.2012.7.1.5

Streitwieser, B.T. (2012). Editorial. Research in Comparative \& International Education, 1, 1-4.

UNESCO (2014). Global Flew of Tertiary level students. Retrieved from: http://www.uis.unesco.org/Education/Pages/international-student-flow-viz.aspx

Yalçun, I. (2011). Social Support and Optimism as Predictors of Life Satisfaction of College Students. International Journal for the Advancement of Counselling, 33, 79-87. http://dx.doi.org/10.1007/s10447-011-9113-9 